\title{
Drain Fly Psychoda spp. (Insecta: Diptera: Psychodidae) ${ }^{1}$
}

\author{
Taryn B. Griffith and Jennifer Gillett-Kaufman²
}

\section{Introduction}

Adult drain flies, Psychoda spp., are commonly seen resting on the walls of bathrooms, building exteriors, and showers near appropriate larval habitats. The larvae can be found feeding on the film of wet organic material that can accumulate in drains. Flies of the genus Psychoda are non-biting (Fair 1934) and are not capable of transmitting any known pathogens; however, large infestations of drain flies can cause respiratory problems due to the possibility of inhaling fine hair-like scales that can fall off their bodies and wings (Boumans et al. 2009).

\section{Distribution}

It is difficult to describe the range of the entire genus Psychoda for that reason we have included the known distribution for one species originally from North America, the drain fly Psychoda alternata. This drain fly has spread to western Asia, Europe, and South America with reports of its establishment in Iraq (Ali et al. 2013), Croatia (Kvifte et al. 2013), Britain (Learner 2000), Norway (Kvifte et al. 2011), Spain (Kvifte et al. 2016), and Brazil (Bravo et al. 2006).

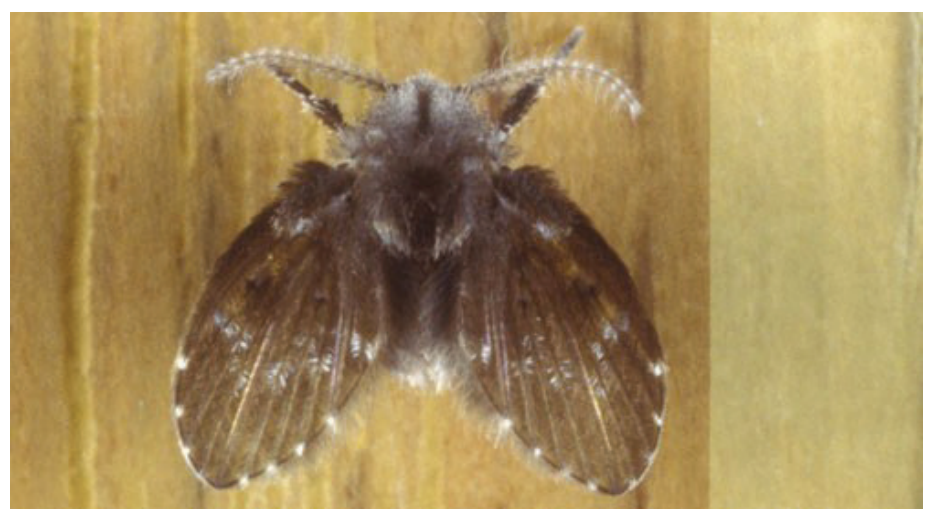

Figure 1. Adult drain fly, Psychoda sp.

Credits: Lyle J. Buss, UF/IFAS

\section{Description and Life Cycle}

Drain flies are holometabolous insects, going through egg, larval, pupal, and adult life stages. Typically, drain flies complete their life cycle in 21 to 27 days (El Bardicy et al. $2009)$, but this accelerates at higher temperatures $\left(85^{\circ} \mathrm{F}\right.$, $29.5^{\circ} \mathrm{C}$ ) (Fair 1934).

\section{Eggs}

Females of Psychoda alternata deposit egg masses on the wet or moist soil, sides of drains, or other surfaces and will not lay eggs on dry surfaces (El Bardicy et al. 2009). Single eggs and masses up to 100 eggs have been reported; however, masses of 15 to 40 eggs are most common. Eggs are small, no larger than $1 \mathrm{~mm}$, and are transparent (Fair

1. This document is EENY-716, one of a series of the Department of Entomology and Nematology, UF/IFAS Extension. Original publication date October 2018. Visit the EDIS website at https://edis.ifas.ufl.edu for the currently supported version of this publication. This document is also available on the Featured Creatures website at http://entomology.ifas.ufl.edu/creatures.

2. Taryn B. Griffith; and Jennifer Gillett-Kaufman, associate Extension scientist, Department of Entomology and Nematology; UF/IFAS Extension, Gainesville, FL 32611. 
1934). At around $70^{\circ} \mathrm{F}\left(21^{\circ} \mathrm{C}\right)$, eggs will hatch in less than two days (Fair 1934).

\section{Larvae}

The larvae resemble mosquito larvae, in that they are slender, white to creamy brown with a distinct head, welldeveloped mouthparts, and an apparent siphon (Figure 2). The body is made up of 11 segments, with the last two containing paired breathing siphons, often protected by four tracheal papillae (fleshy appendages). On the back (dorsum) of the second larval segment, there are two additional breathing siphons thought to be nonfunctioning (Fair 1934). This is the longest of its life stages, lasting around nine to 15 days at $70^{\circ} \mathrm{F}\left(21^{\circ} \mathrm{C}\right)$, and as few as eight days at $85^{\circ} \mathrm{F}\left(29.5^{\circ} \mathrm{C}\right)$ (Fair 1934). Diapause (overwintering in a state of hibernation) occurs most frequently during the larval stage, but can also occur during the egg and pupal stages.

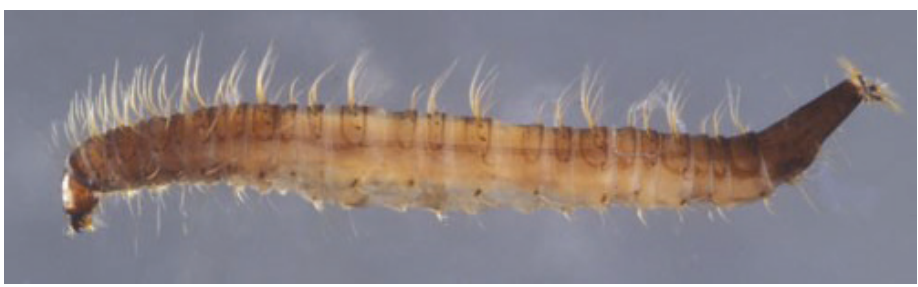

Figure 2. A Psychoda sp., drain fly larva.

Credits: Lyle J. Buss, UF/IFAS

The first larval instars are found within the top five $\mathrm{cm}$ of soil when developing outdoors in wet conditions. This is likely due to eggs being laid on the soil surface. The larvae and pupae usually stay in the top $2.5 \mathrm{~cm}$ of soil; however, they burrow deeper when the soil surface lacks sufficient organic material (Ali et al. 1991). The drain fly larvae must stay towards the top of the soil to breathe (Fair 1934). In addition, a positive correlation has been found between the abundance of organic material at the soil surface and the number of larvae at the surface, suggesting that the larvae may congregate near food sources (Ali et al. 1991). Although larvae are commonly found in the top centimeter of waterlogged soil, they can survive deeper in other materials, such as sewage filter beds, likely due to a higher number of trapped air bubbles (Ali et al. 1991). Additionally, larvae have been known to trap air bubbles using their siphon to withstand prolonged conditions of low oxygen (Fair 1934).

\section{Pupae}

The pupae are yellow to brown, with two respiratory trumpets that look like small horns protruding from the head of the pupa. Pupae require 24 to 48 hours before emerging as an adult (Fair 1934). In temperatures below $46^{\circ} \mathrm{F}\left(7.7^{\circ} \mathrm{C}\right)$, pupation does not occur (Solbé et al. 1971).

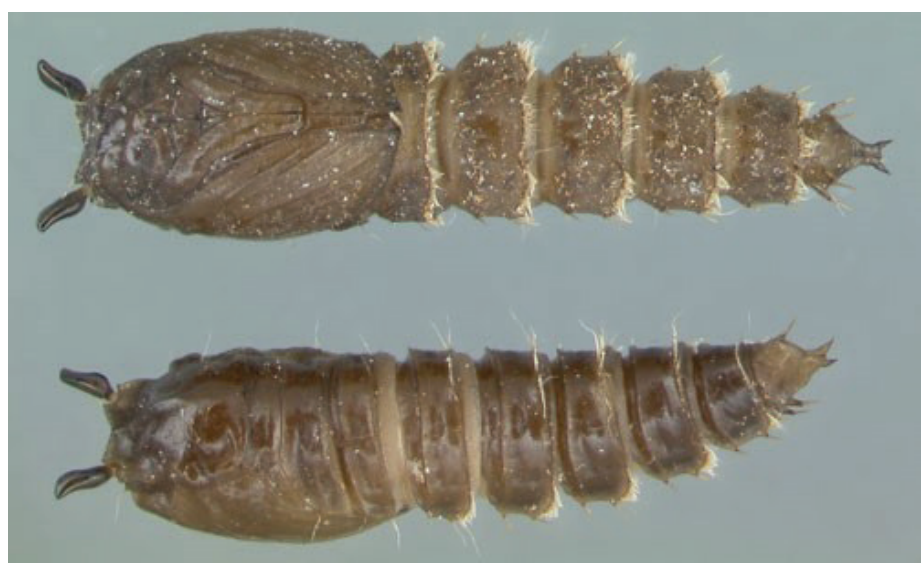

Figure 3. Psychoda sp., drain fly pupae, dorsal and ventral views. Credits: Lyle J. Buss, UF/IFAS

\section{Adults}

Adults have a mottled appearance due to the short, dense hair-like scales present along the wing veins (Figures 1 and 4). Compared to other nematoceran flies, they do not have strong wing muscles, maneuvering mainly by hopping, running, or with short flights. Males emerge before females and live only a few days. Females that have not laid eggs can live up to seven days (Fair 1934). Males are approximately 2.5 to $3 \mathrm{~mm}$ in length, with females slightly larger, on average 4 to $4.5 \mathrm{~mm}$ (Fair 1934). In outdoor situations, adult emergence starts in the beginning of spring and peaks in late summer in temperate regions. Sewage filters with open walls and larger ballast surfaces are ideal larval habitats, as these areas provide a damp environment large enough for the flies to avoid getting flushed down the drain and provide substantial food sources for larvae (Fair 1934).

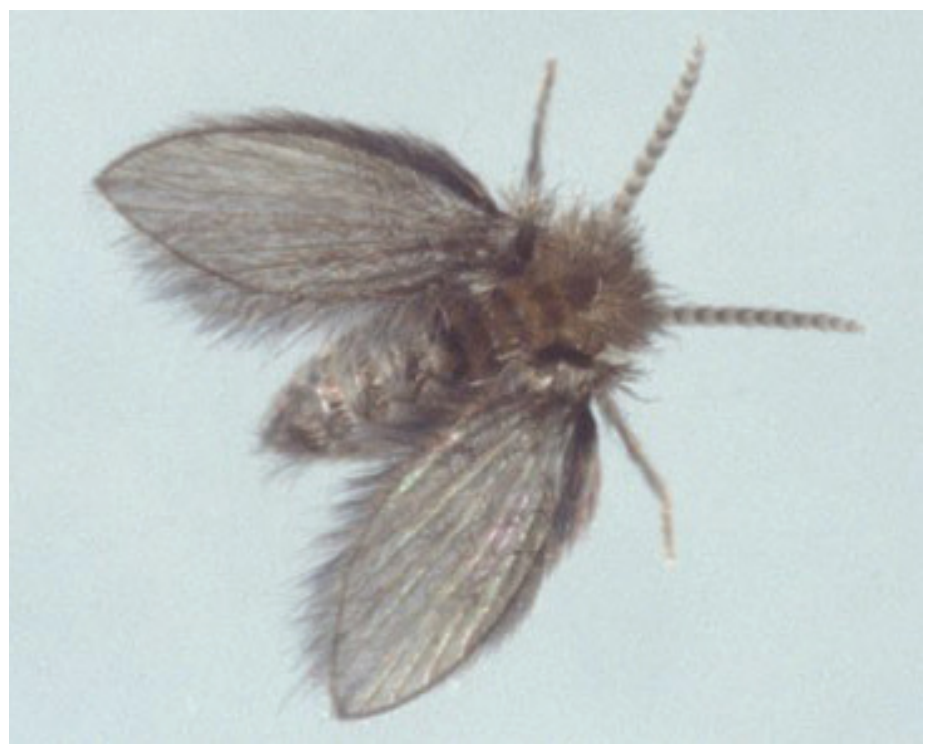

Figure 4. Adult drain fly, Psychoda sp. Credits: Lyle J. Buss, UF/IFAS 


\section{Management}

Drain flies are commonly seen near many types of poorly-maintained drains, inside or out, such as in public bathrooms or at camping sites (Boumans et al. 2009). Due to the poor flight ability of drain flies, locating their immature developmental sites is often easy because it is usually the closest drain. However, the flies can develop in any area with standing water and organic material, in which case the flies are controlled by scraping away organic matter that has built up and drying the area (Headlee 1919).

To confirm if the drain contains flies, place tape over the drain for 24 hours, remove the tape and check for any flies that became trapped while trying to emerge (Nelson 2016, Figure 5). The simplest way to control drain flies is by manually removing the organic material in the drain where eggs are laid and larvae feed. This can be done by taking a metal pipe brush and scraping the inside of the drain. It also is recommended to pour boiling water down the drain to loosen and flush out any organic material that may be missed by the pipe brush (Nelson 2016, Michigan State University 2018).

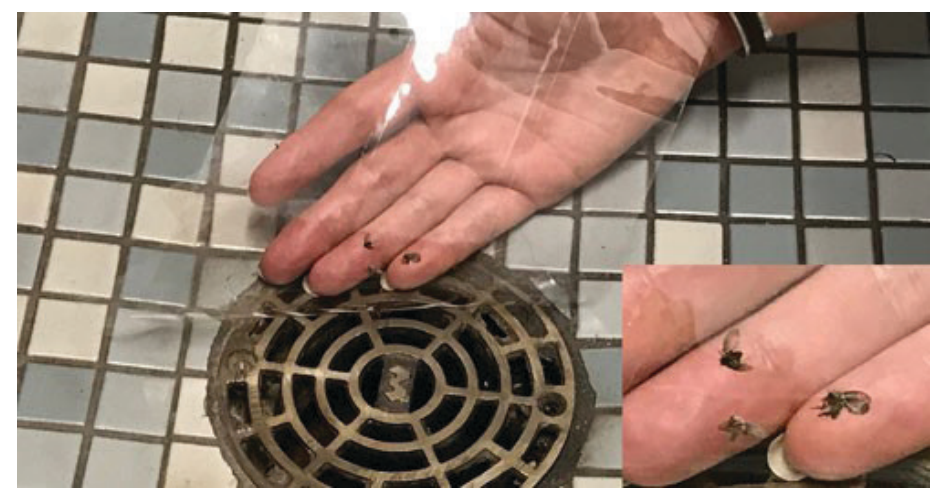

Figure 5. Adult drain flies, Psychoda sp., stuck to clear packing tape. The tape was placed over a drain to monitor for a drain fly infestation. Credits: Jennifer L. Gillett-Kaufman, UF/IFAS

Drain flies do not pose any health threats until they emerge in large numbers, which is not common in most household situations. Drain flies accumulate in higher numbers in waste water systems such as a trickling filter. A trickling filter is a biological treatment that uses microorganisms that attach to a medium of the filter and create a layer of bacteria and other microorganisms known as a biofilm.

Over 200 species of worms, protozoa, bacteria, algae, and insects are known to reside in the microbial biofilm layer of the trickling filter and are utilized by the system to reduce organic material or waste (Mack et al. 1975). Wastewater is deposited over this film and trickles through to a permeable membrane, where the contaminants are treated by the biological processes of these microorganisms (Oakley et al.
2017). The drain fly is not known to damage the community within the microbial film of the trickling filter it lives in; however, its presence can indicate low moisture content in the filter media (Post et al. 2000).

To control larval populations living within the microbial film layer on a trickling filter, submerge the afflicted area in water for 24 to 48 hours. The majority of other organisms in this ecosystem can survive while being submerged for this time. The film will need to be submerged several times a week during the drain fly season to rid the system of Psychoda sp. (Post et al. 2000). The application of the bacteria Bacillus thuringiensis serotype israelensis (Bti) can reduce emergence of the drain fly by $79 \%$ (Houston et al. 1989).

\section{Selected References}

Ali A, Kok-Yokomi ML, Alexander JB. 1991. "Vertical distribution of Psychoda alternata (Diptera: Psychodidae) in soil receiving wastewater utilized for turf cultivation." Journal of the American Mosquito Control Association 2: 287-289.

Ali HB, Augul RSH, Mzhr NN. 2013. "New record of moth fly species; Psychoda alternata Say, 1824 (Diptera: Psychodidae: Psychodinae) from Iraq." Journal of University of Anbar for Pure Science 7: 11-14.

Boumans L, Zimmer JY, Verheggen F. 2009. "First records of the 'bathroom mothmidge' Clogmia albipunctata, a conspicuous element of the Belgian fauna that went unnoticed (Diptera: Psychodidae)." Phegea 37: 153-160.

Bravo F, Cordeiro D, Chagas C. 2006. "Two new species and new records of Psychoda Latreille (Diptera: Psychodidae: Psychodinae) from Brazil, with comments on supraspecific classification of the genus." Zootaxa 1298: 1-15.

El Bardicy S, Tadros M, Yousif F, Hafez S. 2009. "Predatory activity of Psychoda alternata Say (Diptera: Psychodidae) larvae on Biomphalaria glabrata and Lymnaea natalensis snails and the free-living larval stages of Schistoma mansoni." Australian Journal of Basic and Applied Sciences 3: 4503-4509.

Fair G. 1934. "The trickling filter fly (Psychoda alternata), its habits and control." Sewage Works Journal 6: 966-981.

Headlee T. 1919. "Practical application of the methods recently discovered for the control of the sprinkling sewage 
fly (Psychoda alternata)." Journal of Economic Entomology 12: 35-41.

Houston J, Dancer BN, Learner MA. 1989. "Control of sewage filter flies using Bacillus thuringiensis var. israelensis -II. Full scale trials." Water Research 23: 379-389.

Kvifte GM, Håland Ø, Andersen T. 2011. "A revised checklist of Norwegian flies (Diptera, Psychodidae)." Norwegian Journal of Entomology 58: 180-188.

Kvifte GM, Ivkovi M, Klarić A. 2013. "New records of moth flies (Diptera: Psychodidae) from Croatia, with the description of Berdeniella keroveci sp. nov." Zootaxa 3737: 57-67. http://dx.doi.org/10.11646/zootaxa.3737.1

Kvifte GM, Stokkan M, Waggner R. 2016. "Review of the Psychodinae from Mallorca, Spain, with description of Pericoma unipennate, sp. n. (Diptera, Psychodidae)." ZooKeys 557: 149-160. https://doi.org/10.3897/zookeys.577.7679

Learner MA. 2000. "Egression of flies from sewage filter beds." Water Research 34: 877-889.

Mack WN, Mack JP, Ackerson AO. 1975. "Microbial film development in a trickling filter." Microbial Ecology 2: 215-226.

Nelson J. (2016). How to get rid of drain flies naturally. Mother Nature Network. Accessed March 9, 2018. https://www.mnn.com/your-home/at-home/stories/ how-get-rid-drain-flies-naturally

Michigan State University. (2018). Moth flies or drain flies. Michigan State University Diagnostic Services. Accessed March 9, 2018. https://pestid.msu.edu/ insects-and-arthropods/moth-flies-or-drain-flies/

Oakley S, von Sperling M. (2017). Media filters: Trickling filters and anaerobic filters. Global Water Pathogens Project. Accessed March 9, 2018. http://www.waterpathogens.org/ book/media-filters

Post T, Medlock J. (2000). Wastewater technology fact sheet trickling filters. Environmental Protection Agency. EPA832-F-00-014. https://nepis.epa.gov/Exe/ZyPURL. cgi?Dockey=P10099PA.TXT

Solbé LG, Tozer JS. 1971. "Aspects of the biology of Psychoda alternata (Say) and P. severini parthogenetica Tonn (Diptera) in a percolating filter." Journal of Applied Ecology 8: 835-844. 